\title{
CORRIGENDUM
}

\section{Stalin's russocentrism in historical and international context}

\author{
Andreas Umland* \\ Institute for Central and East European Studies (ZIMOS), Katholische Universität Eichstätt- \\ Ingolstadt, Germany
}

Vol. 38, No. 5, September 2010, 741-748

Andreas Umland in his article "Stalin's russocentrism in historical and international context", published in Vol. 38, No. 5, responds to David Brandenberger's "Stalin's populism and the accidental creation of Russian national identity", published in the same issue, suggesting that article largely ignores the research of Erik van Ree, in particular the monograph The Political Thought of Joseph Stalin: A Study in TwentiethCentury Revolutionary Patriotism (London: RoutledgeCurzon, 2002). While the version that had been made available to Andreas Umland did not refer to the monograph, the published version of Brandenberger's article now does in fact include a reference to the aforementioned book.

*Email: andreas.umland@ku-eichstaett.de 